\title{
ANALISIS JUMLAH MIKROBA PADA LAHAN PARKIR DI UIN RADEN INTAN LAMPUNG
}

\author{
Marlina Kamelia ${ }^{1}$ \\ Dwijowati Asih Saputri ${ }^{2}$ \\ Nurhaida Widiani ${ }^{3}$ \\ Novita Nurhasanah ${ }^{4}$
${ }^{1,2,3,4}$ Fakultas Tarbiyah Dan Keguruan, Universitas Islam Negeri Raden Intan Lampung E-mail: ${ }^{1}$ marlinakamelia@ radenintan.ac.id; ${ }^{2}$ dwijowatiasihsaputri@ radenintan.ac.id; ${ }^{3}$ nurhaidawidiani@radenintan.ac.id; ${ }^{4}$ vitanur88@yahoo.com

\begin{abstract}
Vehicle emissions are the residual combustion of fuel in vehicle engines that are imperfect and released through the exhaust system into the air. Vehicle emissions are the main source of air pollution from motorized transportation as a source of movement. Pollutants from motor vehicles, namely $\mathrm{CO}, \mathrm{HC}, \mathrm{NOx}, \mathrm{SO}_{2}$, are chemicals that can cause air pollution. From the results of microbial observations in 9 parking lots of UIN Raden Intan Lampung, it was found that there were differences in the average number of microbes in each parking lot caused by temperature factors, geographical conditions of parking lots and the number of vehicles passing and leaving the parking lot. From the results of data analysis using ANOVA and LSD follow-up tests, the highest number of microbes was found in the parking lot of the Faculty of Economics and Islamic Business (FEBI). The FEBI parking lot ranks 4th in the amount of motor vehicle emissions gas. While the Tarbiyah 2 parking lot has the highest average amount of motor vehicle emissions and with the number of microbes being the second largest after the FEBI parking lot. The observations stated that the effect of the emission gas on the number of bacteria did not significantly influence because the emission gas was still at a moderate level.
\end{abstract}

Kata kunci: mikroba, lahar parkir, analisis jumlah mikroba

\section{PENDAHULUAN}

Udara memiliki peran penting guna menunjang kehidupan makhluk hidup terutama manusia. Udara memiliki ciri khusus berupa tidak terlihat, tidak berbau, tidak berasa tetapi dapat dirasakan dengan adanya angin yang berhembus (Suswati, 2004). Udara terbentuk dari tiga komponen utama yaitu uap air yang berasal dari danau, laut dan tempat-tempat berair lainnya, aerosol yang merupakan substansi berkadar rendah (garam, nitrat, kalsium), dan udara kering yang bermuatan senyawa-senyawa seperti oksigen, nitrogen dan karbon dioksida (Edrie, 2017). Selain ketiga komponen utama udara tersebut, di dalam udara juga terkandung komponen makhluk hidup yaitu mikroorganisme (Fitria dkk, 2008).

Mikroorganisme adalah makhluk hidup yang mikroskopis namun keberadaannya nyata meski tidak bisa langsung terlihat dengan mata. Mikroorganisme di udara berasal dari debu yang diterbangkan oleh angin dari tanah dan dari hasil penguapan tempat berair (laut, sungai), dan berada di udara dalam keadaan membentuk spora. 
Mikroorganisme di udara ada yang dapat bertahan dalam kurun waktu yang lama tetapi ada juga yang bertahan dalam waktu yang singkat tergantung pada spesiesnya dan juga faktor yang mempengaruhinya. (Sudiarta, 2018).

Kehidupan mikroorganisme di udara sangat dipengaruhi oleh lingkungannya, diantaranya yaitu (1) suhu, setiap makhluk hidup memiliki batas suhu terendah dan batas suhu tertinggi begitu juga mikroba, jika suhu terlalu rendah atau terlalu tinggi maka akan mengganggu kehidupannya, (2) senyawa gas, beberapa senyawa seperti oksigen dan nitrogen dapat menunjang kehidupan mikroba tetapi terdapat senyawa yang dapat menghambat kehidupan mikroba contohnya NOx dan $\mathrm{SO}_{2}$, (3) tekanan osmosis, tekanan didalam sel dan di lingkungannya harus seimbang karena jika tidak akan mengakibatkan sel mengalami plasmolisis, (4) radiasi, sinar radiasi seperti sinar UV dari cahaya matahari dengan kadar yang tinggi akan mengganggu kehidupan mikroba (Fithri $\mathrm{dkk}, 2016$ ). Selain beberapa faktor di atas juga terdapat faktor kendaran bermotor.

Kendaran

bermotor

mengeluarkan gas emisi yang mengandung beberapa senyawa diantaranya yaitu uap air $\left(\mathrm{H}_{2} \mathrm{O}\right)$, karbon monoksida $(\mathrm{CO})$, karbon dioksida $\left(\mathrm{CO}_{2}\right)$, nitrogen oksida (NOx) dan sulfur dioksida $\left(\mathrm{SO}_{2}\right)$ (Winarno, 2014). Senyawa senyawa beracun seperti karbon monoksida, hidrokarbon dan sulfur dioksida dapat berbahaya bagi kehidupan makhluk hidup jika kadarnya melebihi batas keamanan yang telah ditentukan (Permatasari, 2014). Mikroba adalah organisme yang menempati udara bebas sehingga mungkin juga terimbas oleh emisi gas buang yang dikeluarkan kendaraan bermotor (Devianti. 2018).

Tujuan yang akan diperoleh dari penelitian ini yaitu untuk mendapatkan perbandingan total jumlah mikroba di lahan parkir Universitas Islam Negeri Raden Intan Lampung sehingga dapat menjadi rekomendasi bagi institusi untuk pengelolaan lahan parkir.

\section{METODE}

Penelitian ini dilakukan pada bulan September 2018 di laboratorium terpadu UIN Raden Intan Lampung. Jenis penelitian ini adalah studi komparatif dengan pengambilan sampel secara purposive random sampling. Penelitian ini dilakukan dalam 5 tahap yaitu tahap pertama pembuatan media, tahap kedua pengambilan sampel, tahap ketiga pengamatan, dan tahap keempat yaitu analisis data.

Tahap Pertama, yaitu menyiapkan media tumbuh bagi bakteri dan jamur yang akan diamati. Media disini menggunakan media NA (Nutrient Agar) dan media PDA (Potato Dextrose Agar). Pembuatan media NA dengan cara menimbang media sebanyak 14 gram dilarutkan dalam $500 \mathrm{ml}$ aquades. Sedangkan media PDA dibuat dengan media sebanyak 18 gram dilarutkan dalam $500 \mathrm{ml}$ aquades. Setelah itu masing-masing media dihomogenkan dengan Erlenmeyer dan dipanaskan. Media yang telah dipanaskan disterilkan dengan menggunakan autoklaf pada suhu $121^{\circ} \mathrm{C}$ selama 15 menit. Kemudian didinginkan sampai suhu $45-50^{\circ} \mathrm{C}$. Pada media PDA ditambahkan antibakteri Chloramphenicol $500 \mathrm{mg}$, setelah itu 
media dituang pada cawan petri dan diinkubasi selama 24 jam untuk uji anti mikroba.

Tahap Kedua, melakukan pengambilan sampel di 9 lahan parkir yang terdapat di UIN Raden Intan Lampung dengan cara membuka media di udara bebas selama 15 menit lalu ditutup kembali dan diinkubasi di inkubator selama 24 jam untuk NA dan 72 jam untuk PDA.

Tahap Ketiga, pengamatan sampel. Pengamatan sampel dilakukan dengan 3 tahap pengamatan, (1) pengamatan total jumlah mikroba dengan menggunakan metode TPC (Total Plate Count), (2) pengamatan morfologi dan sifat mikroba. Pada koloni mikroba yang diamati yaitu bentuk, warna, ukuran, sisi, dan bentuk permukaan. Pada sifat bakteri dengan menggunakan pewarnaan gram dan pada jamur diamati hifa dan spora.
Tahap Keempat, analisis data dengan menggunakan uji One Way ANOVA taraf 5\% dan jika dinyatakan signifikan maka dilanjutkan dengan uji lanjutan LSD (Least Significant Different).

Selain pengambilan data primer seperti di atas, dilakukan juga pengambilan data sekunder. Data sekunder berupa suhu dan kelembaban udara serta menghitung jumlah kendaraan yang dijadikan dasar penghitungan beban emisi gas $\mathrm{CO}, \mathrm{HC}$, $\mathrm{NO}_{x}$, serta SO2.

\section{HASIL}

Rata-rata jumlah bakteri dan jamur pada 9 lahan parkir di lahan parkir UIN Raden Intan Lampung menunjukkan perbedaan yang signifikan berdasarkan hasil uji lanjut LSD pada taraf 5\% (lihat Tabel 1).

Tabel 1. Jumlah Bakteri dan Jamur di Area Parkir

\begin{tabular}{|l|l|l|}
\hline \multirow{2}{*}{\multicolumn{1}{|c|}{ Area Parkir }} & \multicolumn{2}{|c|}{ Bilai rata-rata \pm SD } \\
\cline { 2 - 3 } & \multicolumn{1}{|c|}{ Bakteri } & \multicolumn{1}{c|}{ Jamur } \\
\hline Rektorat & $4,33 \times 10^{2 \mathrm{a}} \pm 101,93$ & $1,6 \times 10^{\mathrm{ad}} \pm 1,53$ \\
\hline Akademik pusat & $5,05 \times 10^{2 \mathrm{ac}} \pm 60,04$ & $1,5 \times 10^{\mathrm{abd}} \pm 7,64$ \\
\hline Perpustakaan pusat & $5,40 \times 10^{2 \mathrm{abc}} \pm 64,50$ & $8 \times 10^{-1 \mathrm{bc}} \pm 2,08$ \\
\hline Fakultas Dakwah & $4,44 \times 10^{2 \mathrm{ac}} \pm 74,11$ & $1,6 \times 10^{\mathrm{abd}} \pm 5,29$ \\
\hline Fakultas Syariah & $5,46 \times 10^{2 \mathrm{abc}} \pm 58,35$ & $1 \times 10^{\mathrm{abc}} \pm 3,79$ \\
\hline $\begin{array}{l}\text { Fakultas Ekonomi dan } \\
\text { Bisnis Islam }\end{array}$ & $6,61 \times 10^{2 \mathrm{~b}} \pm 99,38$ & $2,1 \times 10^{\mathrm{d}} \pm 5,57$ \\
\hline Fakultas Ushuluddin & $5,26 \times 10^{2 \mathrm{ac}} \pm 66,30$ & $7 \times 10^{-1 \mathrm{c}} \pm 1,00$ \\
\hline Fakultas Tarbiyah 1 & $5,17 \times 10^{2 \mathrm{ac}} \pm 66,16$ & $1,2 \times 10^{\mathrm{ac}} \pm 4,04$ \\
\hline
\end{tabular}




\begin{tabular}{|l|l|l|}
\hline Fakultas Tarbiyah 2 & $5,66 \times 10^{2 \mathrm{bc}} \pm 28,75$ & $1,3 \times 10^{\mathrm{ac}} \pm 3,51$ \\
\hline
\end{tabular}

Sumber: Data Terolah

Keterangan : Angka yang diikuti dengan huruf yang berbeda menunjukkan berbeda nyata pada taraf $5 \%$.

Tabel di atas menjelaskan bahwa pada rata-rata jumlah bakteri dan jamur yang tertinggi berada di lahan parkir Fakultas Ekonomi dan Bisnis Islam dengan rata-rata bakteri $6,61 \times 10^{2}(661)$ dan rata-rata jumlah jamur 2,1x10 (21). Lahan parkir FEBI memiliki jumlah bakteri dan jamur tertinggi.

\section{PEMBAHASAN}

Data hasil megungkap lahan parkir FEBI memiliki jumlah bakteri dan jamur tertinggi dikarenakan beberapa faktor (1) keadaan geografis lahan parkir FEBI dengan tekstur tanah berpasir yang mudah menjadi debu ketika tertiup angin, (2) angin, angin dapat menerbangkan tanah menjadi debu yang membawa mikroba ke udara, sesuai dengan penelitian Lymperopoulou (2016) yang menyatakan bakteri akan lebih banyak terdapat di tempat berangin dibandingkan dengan tempat yang kurang berangin, (3) letak lahan parkir FEBI yang berada di sisi yang berdekatan dengan jalan yang menjadi lalu lintas masuk dan keluar kampus, sesuai dengan penelitian yang dilakukan oleh Bartlett (2003) bahwa tingginya konsentrasi mikroba di udara dikarenakan oleh keadaan lahan yang lebih dinamis oleh adanya kendaraan yang melintas. Selain itu, menurut Bowers (2011) bakteri yang melimpah di atmosfer menjadi komponen sebagian besar partikel organik. Bakteri patogen pada tanaman, ternak, maupun manusia biasanya tersebar di atmosfer yang dapat memicu berbagai macam reaksi alergi. Namun, udara sesungguhnya bukan media tumbuh mikroba sehingga yang dapat ditemukan hanya dalam bentuk spora. Mikroba dalam bentuk spora bila berada dalam kondisi tidak mungkin tumbuh. Udara yang berisi spora mikroba ini apabila terhirup atau bersinggungan dengan kulit dapat mengganggu kesehatan (Mouli, 2005).

Jumlah bakteri dan jamur yang diamati pada waktu pagi, siang, maupun sore hari menunjukkan perbedaan sebagaimana tampak pada Tabel 2 dan 3 berikut :

Tabel 2. Jumlah Bakteri Berdasarkan Waktu Pengamatan

\begin{tabular}{|l|l|l|l|l|l|l|l|}
\hline \multirow{2}{*}{ No } & \multirow{2}{*}{ Lahan Parkir } & \multicolumn{2}{|l|}{ Pagi } & Siang & \multicolumn{2}{l|}{ Sore } \\
\cline { 3 - 8 } & & Jumlah & Rerata & Jumlah & Rerata & Jumlah & Rerata \\
\hline 1. & Rektorat & 541 & 180 & 453 & 151 & 308 & 103 \\
\hline 2. & $\begin{array}{l}\text { Akademik } \\
\text { Pusat }\end{array}$ & 799 & 266 & 447 & 149 & 403 & 134 \\
\hline 3. & Perpus Pusat & 429 & 143 & 599 & 200 & 491 & 164 \\
\hline 4. & F. Dakwah & 656 & 219 & 349 & 116 & 424 & 141 \\
\hline 5. & F. Syari'ah & 677 & 226 & 444 & 148 & 432 & 144 \\
\hline
\end{tabular}


M. KAMELIA, DWIJOWATI, A. SAPUTRI, N. WIDIANI, N. NURHASANAH, ANALISIS..

\begin{tabular}{|l|l|l|l|l|l|l|l|}
\hline 6. & F. EBI & 799 & 266 & 707 & 236 & 651 & 217 \\
\hline 7. & F. Ushuluddin & 406 & 135 & 750 & 250 & 620 & 207 \\
\hline 8. & F. Tarbiyah 1 & 783 & 261 & 454 & 151 & 512 & 171 \\
\hline 9. & F. Tarbiyah 2 & 513 & 171 & 637 & 212 & 390 & 130 \\
\hline \multirow{2}{*}{} & Jumlah & 1876 & & 1613 & & 1411 \\
\cline { 2 - 3 } & Rata-rata & 208,44 & & 179,22 & & 156,78 \\
\hline
\end{tabular}

Sumber : Data Terolah

Tabel 3. Jumlah Jamur Berdasarkan Waktu Pengamatan

\begin{tabular}{|c|c|c|c|c|c|c|c|}
\hline \multirow[b]{2}{*}{ No } & \multirow[b]{2}{*}{ Lahan Parkir } & \multicolumn{2}{|l|}{ Pagi } & \multicolumn{2}{|c|}{ Siang } & \multicolumn{2}{|l|}{ Sore } \\
\hline & & $\begin{array}{l}\text { Jumla } \\
\text { h }\end{array}$ & $\begin{array}{l}\text { Rera } \\
\text { ta }\end{array}$ & $\begin{array}{l}\text { Juml } \\
\text { ah }\end{array}$ & $\begin{array}{l}\text { Rera } \\
\text { ta }\end{array}$ & $\begin{array}{l}\text { Juml } \\
\text { ah }\end{array}$ & $\begin{array}{l}\text { Rera } \\
\text { ta }\end{array}$ \\
\hline 1. & Rektorat & 14 & 5 & 20 & 7 & 14 & 5 \\
\hline 2. & $\begin{array}{l}\text { Akademik } \\
\text { Pusat }\end{array}$ & 24 & 8 & 14 & 5 & 9 & 3 \\
\hline 3. & Perpus Pusat & 7 & 2 & 8 & 3 & 8 & 3 \\
\hline 4. & F. Dakwah & 20 & 7 & 10 & 3 & 17 & 6 \\
\hline 5. & F. Syari'ah & 12 & 4 & 6 & 2 & 10 & 3 \\
\hline 6. & F. EBI & 26 & 9 & 11 & 4 & 18 & 6 \\
\hline 7. & F. Ushuluddin & 8 & 3 & 8 & 3 & 6 & 2 \\
\hline 8. & F. Tarbiyah 1 & 11 & 4 & 10 & 3 & 17 & 6 \\
\hline \multirow[t]{3}{*}{9.} & F. Tarbiyah 2 & 17 & 6 & 13 & 4 & 10 & 3 \\
\hline & \multicolumn{2}{|l|}{ Jumlah } & 48 & & 34 & & 37 \\
\hline & \multicolumn{2}{|l|}{ Rata-rata } & 5,33 & & 3,78 & & 4,11 \\
\hline
\end{tabular}

Sumber : Data Terolah

Tabel di atas menjelaskan bahwa rata-rata jumlah bakteri dan jamur dengan waktu pengambilan sampel pada pagi, siang dan sore hari. Jumlah dan rata-rata bakteri dan jamur tertinggi pada pagi hari dengan jumlah bakteri sebanyak 1876 koloni dan jumah jamur sebanyak 48 koloni.

Suhu merupakan faktor utama yang mempengaruhi keberadaan mikroba di udara. Suhu pada pagi hari lebih rendah dibandingkan dengan siang dan sore hari. Hasil penelitian menunjukkan suhu udara berkisar antara $27-31^{\circ} \mathrm{C}$ pada pagi hari, $32-36^{\circ} \mathrm{C}$ pada siang hari dan $30-35^{\circ} \mathrm{C}$ pada sore hari.
Secara rata - rata suhu udara harian antara $26-35^{\circ} \mathrm{C} \quad$ Suhu udara yang rendah mengakibatkan kelembaban udara semakin meningkat dan kelembaban pada siang hari cenderung lebih rendah dibandingkan dengan pagi hari. Kelembaban udara sebesar 67 $75 \%$ pada pagi hari, sedangkan turun pada siang hari dikisaran 46 - 50\% dan mengalami peningkatan kembali di sore hari sebesar 55 - 62\%. Suhu dan kelembaban yang berubah mengakibatkan bakteri dan jamur pada siang dan sore hari lebih rendah dibandingkan pada pagi hari karena kelembaban yang rendah dapat 
menyebabkan selaput lendir membran mengalami kekeringan, sementara kelembaban yang tinggi akan meningkatkan pertumbuhan mikroba (Ooyama, 2012). Hasil penelitian menunjukkan intensitas cahaya matahari di lahan terbuka seperti ruang parkir tanpa naungan adalah 586,7 - 13490,1 lux, sedangkan pada tempat ternaungi rata-rata sebesar 2214,44 lux (Susanto, dkk; 2015). Intensitas cahaya matahari akan menyebabkan peningkatansinar ultraviolet dan berimbas juga pada meningkatnya suhu udara. Cahaya matahari akan meningkatkan sinar UV yang diiringi dengan kenaikan kadar Ozon $\left(\mathrm{O}_{3}\right)$. Oleh karena itu sinar UV pada siang hari sangat tinggi yang mengakibatkan jumlah mikroba pada siang hari lebih sedikit dibandingkan dengan pagi hari. menyebabkan dimerisasi basa DNA pada mikroba. Absorbsi maksimal sinar UV di dalam sel terjadi pada asam nukleat yang menyebabkan dimerisasi basa DNA pada mikroba tersebut. Selain itu diperkirakan mekanisme lain perusakan sel oleh sinar UV pada ribosom, sehingga mengakibatkan terjadinya mutasi atau kematian sel (Aryadi \& Dewi, 2009).

Gas emisi yang diamati dalam penelitian ini adalah gas emisi karbon monoksida (CO), hidrokarbon (HC), nitrogen oksida (NOx) dan sulfur dioksida $\left(\mathrm{SO}_{2}\right)$. Hasil perhitungan emisi gas buang dihitung berdasarkan jumlah kendaraan bermotor yang masuk pada setiap lahan parkir. Jumlah kendaraan bermotor pada masing-masing lahan parkir dihitung selama 3 hari berturutturut dari tanggal 4 hingga 6 September 2018, pada pukul 07.30-15.30 WIB, dimana tiap jamnya dilakukan pengamatan selama 15 menit. Setelah diketahui jumlah kendaraan selanjutnya dihitung jumlah gas emisi yang dihasilkan. Hasil penghitungan jumlah kendaraan bermotor serta gas emisi secara berurutan tampak pada tabel 4 dan grafik 1 berikut:

Tabel 4. Data kendaraan bermotor pada tiap-tiap lahan parkir

\begin{tabular}{|l|l|l|l|l|}
\hline \multirow{2}{*}{ No } & \multirow{2}{*}{ Tempat Parkir } & \multicolumn{2}{|l|}{ rata-rata } & \multirow{2}{*}{ jumlah } \\
\cline { 3 - 4 } & & mobil & motor & \\
\hline 1 & Rektorat & 66 & 134 & 200 \\
\hline 2 & Akademik Pusat & 77 & 205 & 282 \\
\hline 3 & Perpus Pusat & 80 & 223 & 304 \\
\hline 4 & F.Dakwah & 53 & 117 & 170 \\
\hline 5 & F. Syari'ah & 93 & 248 & 341 \\
\hline 6 & FEBI & 76 & 167 & 243 \\
\hline 7 & F. Ushuluddin & 110 & 290 & 400 \\
\hline 8 & Tarbiyah 1 & 165 & 486 & 651 \\
\hline 9 & Tarbiyah 2 & 182 & 445 & 627 \\
\hline
\end{tabular}

Sumber; Data Terolah 


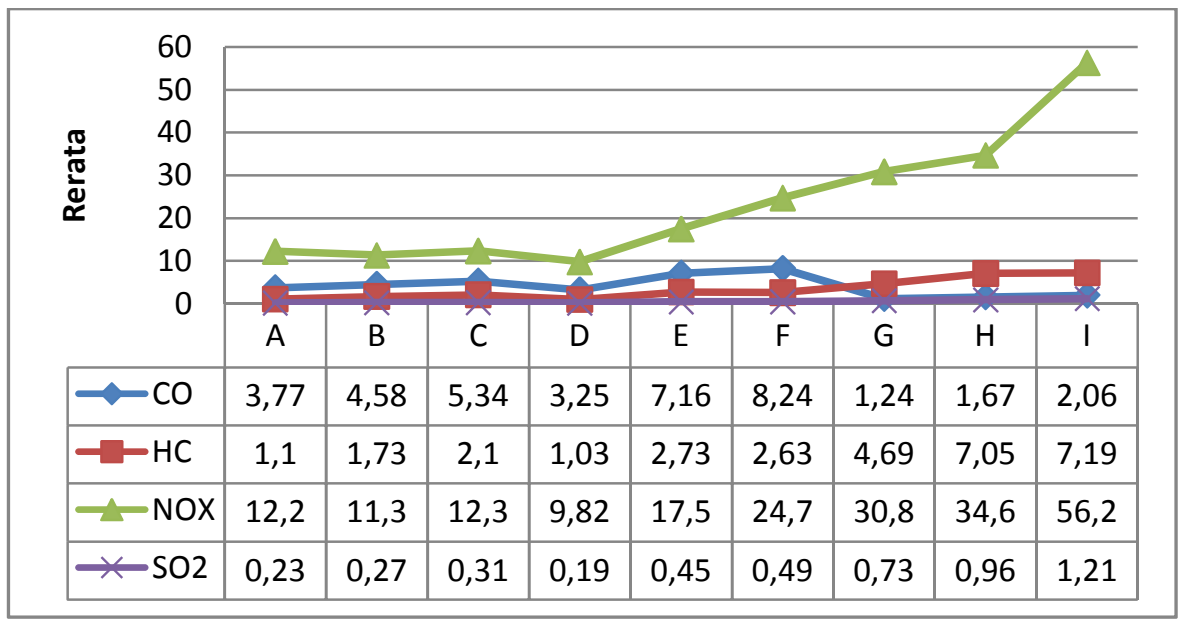

Gambar 1 : Grafik: Rerata Emisi CO, $\mathrm{HC}, \mathrm{NO}_{\mathrm{x}}$, dan $\mathrm{SO}_{2}$

Misi gas buang kendaraan bermotor pada masing-masing lahan parkir dari terendah ke tertinggi secara berurutan yaitu rektorat, akademik pusat, perpustakaan pusat, dakwah, syari'ah, FEBI, ushuludin, tarbiyah 1, dan tarbiyah 2. Rata-rata gas emisi $\mathrm{CO}$ didapatkan hasil 1,24-8,24, HC: 1,10-7,19, NOx: 9,82-56,25, $\mathrm{SO}_{2}$ : 0,19-1,21. Sedangkan rentang tingkat pencemaran udara ambien yang telah ditetapkan oleh Kementerian Negara Lingkungan Hidup tahun 2006 menyatakan bahwa ambang batas gas emisi berkisar antara SOx: 0,001-0,276, CO: 0.01-11,53. Sehingga hasil yang didapatkan dari lahan parkir UIN Raden Intan Lampung masih dalam taraf sedang. Jumlah mikroba menyatakan bahwa bakteri dan jamur terbanyak terdapat di lahan parkir FEBI dan lahan parkir FEBI menempati urutan gas emisi terbanyak ke4 dari banyaknya gas emisi di lahan parkir. Sedangkan lahan parkir tarbiyah 2 menempati urutan gas emisi tertinggi di lahan parkir dengan jumlah bakteri terbanyak ke-2 setelah lahan parkir FEBI. Hasil ini menyatakan bahwa gas emisi tidak berpengaruh secara signifikan terhadap jumlah mikroba yang ada di udara. Namun, kondisi lahan yang mempengaruhi jumlah total mikroba. Lahan parkir dengan total jumlah koloni mikroba tertinggi yaitu pada lahan yang masih berupa tanah berpasir. Hal ini dikarenakan butiran debu dan pasir, yang didalamnya terdapat spora jamur atau bakteri, akan mudah terbang ke udara saat lalu lintas kendaraan.

\section{KESIMPULAN}

Kesimpulan dari penelitian ini adalah total koloni bakteri tertinggi adalah di Fakultas Ekonomi dan Bisnis Islam sedangkan jamur di Akademik Pusat. Total jumlah mikroba tertinggi yaitu pada waktu pengambilan sampel pagi hari dan terendah di siang hari. Suhu, kelembaban, serta kondisi lahan parkir mempengaruhi total jumlah mikroba sedangkan emisi gas buang kendaraan tidak berkorelasi.

\section{SARAN}

Saran untuk peneliti selanjutnya untuk mengidentifikan mikroba patogen yang ada di lahan parkir karena mikroba patogen umumnya lebih tahan pada 
kondisi yang ekstrim semisal golongan archaebakteria.

\section{DAFTAR RUJUKAN}

Aryadi dan S. Dewi. 2009. Pengaruh Sinar Ultra Violet Terhadap Pertumbuhan Bakteri Bacillus Sp. Sebagai Bakteri Kontaminan. Jurnal Ilmu Kesehatan. 2(2): 2025.

Bartlett. 2003. Report on Evaluatig Indoor Air Quality: Test Standarts for Bioaerosols. Columbia: University of British Columbia.

Bowers, R. M. 2011. Sources of Bacteria in Outdoor Air across Cities in the Midwestern United States. Amerika: American Society for Microbiology.

Devianti, M. 2018. Model Emisi Gas Buangan Kendaraan Bermotor Akibat Aktivitas Transportasi (Studi Kasus : Terminal Pasar Bawah Ramayana Kota Bandar Lampung)". JRSDD. 3(1): 57 70.

Edrie, F. M. 2017. Analisis pengaruh variasi temperatur fluida pada kondisi lingkungan kering dan basah terhadap karakteristik korosi pipa baja terinsulasi berbahan glasswool dan aluminium foil. Skripsi Tidak diterbitkan. Institut Teknologi Sepuluh Nopember.

Fitria, L., R. A. Wulandari, E. Hermawati, \& D. Susanna. 2008. Kualitas Udara Dalam Ruang Perpustakaan Universitas "X" Ditinjau Dari Kualitas Biologi, Fisik, Dan Kimiawi. Makara, Kesehatan, 12 (2): 77-83.
Fithri, Nayla Kamilia; Putri Handayani; Gisely V. 2016. Faktor-Faktor Yang Berhubungan Dengan Jumlah Mikroorganisme Udara Dalam Ruang Kelas Lantai 8. Jurnal Bunga Rampai. 13 (01): 23-35.

Kementerian Negara Lingkungan Hidup. 2006. Ambang Batas Emisi Gas Buang Kendaraan Bermotor. Jakarta.

Lymperopoulou, D. S. 2016. Contribution of Vegetation to the Microbial Composition of Nearby Outdoor Air. California USA: American Society for Microbiologi.

Mouli P. M.. 2005. Assessment of microbial (bacteria) Concentrations of ambient air at semi-arid urban region: Influence of meteorological factors: Applied ecology and environmental research. Applied. 3(2): 139-149

Ooyama, Y. \& Harima, Y. 2012. Photophysical and electrochemical properties, and molecular structures of organic dyes for dyesensitized solar cells. Chemphyschem, 13, 4032-80.

Peraturan Pemerintah Republik Indonesia nomor 41. 1999. Standar Kualitas Udara Ambien. Jakarta.

Permatasari, A. I. A. 2014. Analisis Pemetaan Kualitas Udara Ambien Menggunakan Perangkat Lunak ARCGIS 10 dan Model Dispersi GAUSS (Studi Kasus Kawasan Bukit Semarang Baru Kecamatan Mijen, Kota Semarang). Masters Thesis, Program Magister Ilmu Lingkungan.

Susanto, A., E. S. Muliawati, \& D. Purnomo. 2015. Kajian Ekologi, 
M. KAMELIA, DWIJOWATI, A. SAPUTRI, N. WIDIANI, N. NURHASANAH, ANALISIS.

Keanekaragaman Jenis Dan

Potensi Pohon Di Pekarangan (Studi Kasus Di Desa Kebak, Jumantono, Karanganyar). Journal of Sustainable Agriculture,30(1): 33-40.

Suswati, A. C. S. Purna dan S. Y. M. Taneo. 2004. Respon Masyarakat Penghuni Permukiman Sekitar Industri Keramik Terhadap Pencemaran Udara Akibat Aktivitas Pembakaran Keramik.
Jurnal Manusia dan Lingkungan. 11(3): 103-111.

Sudiarta, I. N., \& I. M. T. Semara, 2018. Sanitasi, Hygiene dan Keselamatan Kerja. Jurnal Ilmiah Hospitality Management. 8(2): 110.

Winarno, J. 2014. Studi Emisi Gas Buang Kendaraan Bermesin Bensin Pada Berbagai Merk Kendaraan dan Tahun Pembuatan. 1(1): 1-9. 